\title{
Social Services Administration in Gwagwalada Area Council: Militating Factors
}

\author{
Irechukwu Eugenia Nkechi (Corresponding author) \\ Kigali Institute of Management \\ P.O. Box 2895, Kigali, Rwanda
}

Ph:(250)788834116_Email: irenkechi@yahoo.com

\author{
Chima Paul \\ Department of Public Administration \\ University of Abuja, Gwagwalada, Nigeria \\ Ph:(234)8058984189Ｅmail: chimapaul@yahoo.com
}

Received: May 22, 2012 Accepted: October 02, 2012 DOI: 10.5296/jpag.v2i3.2499

\begin{abstract}
This study attempted to determine the factors militating against effective social services administration and its unfolding empirical manifestations on the well-being of the rural dwellers in Gwagwalada Area Council in Abuja, Nigeria as well as its attendant effects on rural development. Based on the data generated from 200 respondents (rural residents and staff of the area council) using questionnaire, interview and personal observation, it was discovered that lack of involvement of the rural dwellers in decisions regarding the design and implementation of the social service programmes by the Council is one of the key factors. The paper recommends accordingly among others, that effective social services administration should reflect the wishes and aspirations of beneficiaries.
\end{abstract}

Keywords: Rural, Development, Administration, Social, Services, Nigeria. 


\section{Introduction}

The importance of social services to the existence of human society cannot be underestimated. Social services effectively administered would no doubt improve the standard of living of the people in the rural area. Therefore, any developmental approach that negates effective delivery of social services is anti human, and is as good as not being carried out, because, development should be human-centred. In an effort to cater for the well-being of the rural dwellers in the Gwagwalada Area Council, different administrative units have been put in place to render social services to residents of the area council. However, despite these administrative initiatives to reduce to the barest minimum the social problems and thereby improving the well-being and rural development, the area council has not been able to meet up with her social development goals.

Poverty, social inequality, crime, massive illiteracy, and other social vices characterised the rural dwellers in the area council. These manifest in so many dimensions such as poor shelter, lack of qualitative education, health centre and other social amenities which could better the lots of an ordinary man in the rural areas. In a related study conducted on the area council, Ekhator (2008) maintained that "the administration of social services in the area council ought to be effectively carried out to improve the living standard of the communities, but unfortunately the reverse is the case".

Yet, in a recent related study by Babatunde (2010) on the state of social amenities and its impact on the quality of life in rural area of Gwagwalada area council, it was revealed that service delivery in education, health, water, transport, electricity and housing are in poor state and hence negative impact on the life of the residents. Deducing from the above, it is evident that the Area Council has not been living up to her constitutional responsibility of providing for the welfare of residents in the rural settings. Therefore, the study intends to find out the administrative lapses which are thwarting effective administration of social service programmes in the area council and by extension the rural development.

\section{Objectives of the Study}

The general objective of the study is to identify the factors militating against effective administration of social services in Gwagwalada Area Council. The specific objectives are to:

i. Ascertain the extent to which the target group (beneficiaries of social services) are made partners in the course of designing and implementing of social services in the Area Council;

ii. examine if the Area Council has specialists and motivated staff to administer social services in the council's rural sectors;

iii. find out if there is proper coordination and network between the Area Council and other organisations providing social services in the rural areas; and

iv. Identify if the Area Council has substantial baseline data on the area of interventions in meeting the social needs of the vulnerable groups. 


\section{The Concept of Social Service}

Beula cited in Ekhator (2008) defined social service comprehensively as the services rendered and supervised by social workers in response to a need expressed by an individual or a family and related to their social adjustment. This is very suitable for the purpose of this study as it identified a fundamental factor being examined. This factor is the "expressed needs" by the concerned target group. This presupposes that social service rendered to the rural dwellers is not a charity, but, an obligation to fulfil the term of contract between the government and the governed. For Spicker (1995) social service has a wider connotation more than health, education, social security and housing. A wider understanding according to Spicker encompasses a variety of other services such as sanitation, employment and legal services. On the whole, social service is seen in this study as the services provided by governmental body like Gwagwalada Area Council for the welfare of the people living within her rural environs. Such services include quality and affordable primary education, housing, primary health care, temporal accommodation for destitute and effective securities services for lives and properties.

\subsection{Social Services Administration and Rural Development}

Administration is the organisation and direction of persons and material in order to accomplish a specified end (Ekhator, 2002). Social services well-administered, is a prerequisite to rural development. Social services are elements in the package of basic needs which a community may want to procure to enhance the quality of rural life. When social services are well executed, productivity of the rural economy would increase. When it does not work, citizens suffer, particularly the poor. Rural areas in Nigeria are generally deprived of the basic social needs of life such as housing, medical care, education, recreation, credit facilities for self-improvement. Studies in Nigeria show a high degree of inequality in income distribution (Modupe, 1986; World Bank, 1997) and in the provision of social-economic opportunities and facilities between rural and urban areas (Mabogunje, 1977 and Stewart, 1985) in which rural areas are less favoured due to absence or poor administration of social services. A social service well articulated according to Smalley (1966), Olowa (1987), guarantees two values to recipients. These according to them is respect for the worth and dignity of every individual and the concern that he has opportunity to realise his potential as an individually fulfilled, socially contributive person. Migration from rural to urban cities by able bodied young men and women would also be reduced.

However, administration of social services is thwarted by so many factors. In some cases, lack of policy commitment and misallocation of resources as well as absence of effective institutional framework could be a factor. Apart from the above and in specific to Nigeria circumstance, administrative and governance arrangement that the post-colonial independence leaders adopted was a major factor. The arrangement was too centralised. Thus, government attentions were directed at few urban centres in terms of social services facilities to the neglect of the rural areas. Social services, no doubt, if well administered would affect positively the lives of the rural dwellers and perhaps the development of the rural areas. But, this arrangement is not obtainable due to some of the factors mentioned above. 


\section{1) Macrothink}

\section{Research Methodology}

\subsection{The Study Area}

The study location is Gwagwalada Area Council, one of the area councils among the six area councils in the Federal Capital Territory, Abuja, Nigeria. It has land mass of 1,043 square kilometres and a population of 157,770 as at the 2006 census (CSCDE, 2008). The area council has ten wards which include: Dobi, Gwagwalada Central, Gwako, Ibwa, Ikwa, Kutunku, Paiko, Quarters, Tungamaje and Zuba. The inhabitants are mainly Gwari, Bassa, Housa-Fulani, koro and Gede. Farming is the main stay of the local population.

\subsection{Sampling Techniques}

Multistage sampling techniques were employed in this study to get respondents from the rural areas. In the first stage, five wards were chosen randomly out of the ten wards in Gwagwalada Area Council. The second stage involved the selection of two rural communities from each of the five wards making a total of ten communities. The last stage involved the selection of ten households of the ten communities making a total of 100 respondents from the rural communities. The wards and the community chosen are as below:

\begin{tabular}{|l|l|l|}
\hline S/No & Wards & Communities \\
\hline 1 & Kutunku & Kutunku Tsoho and Kutunku Kaida \\
\hline 2 & Paiko & Paiko Kore and Katse \\
\hline 3 & Tungamaje & Angwan Gede and Angwan Samu \\
\hline 4 & Gwako & Gwako I and Gwako II \\
\hline 5 & Dobi & Dobi Centre and Kaida Sabo \\
\hline
\end{tabular}

Using Yaro Yamani's formula at 95\% level of confidence and 5\% error margin, the sample size from the staff strength of 500 of the Council is as below:

$$
\frac{\mathrm{N}}{\mathrm{n}=1+\mathrm{N}(\mathrm{e})^{2}}
$$

Where $\mathrm{N}=$ Population of Area Council Staff

$\mathrm{e}=$ Margin of error i.e. 0.05

$\mathrm{n}=$ Sample size

Thus, the sample size for the study is

$$
\mathrm{n}=\frac{500}{1+500(0.05)^{2}}
$$


$\mathrm{n}=$ 500

$$
\mathrm{n}=\frac{500}{3.0025}
$$

$\mathrm{n}=399.7 \simeq 400$

Thus, making a total of 500 respondents (100 rural residents and 400 staff of the council).

\subsection{Analytical Techniques}

Descriptive statistical techniques were used in analysing the data. The descriptive analysis involves the construction of frequency tables. These were used to describe and compare the opinions of the respondents. Chi-square was also used to test the hypotheses. The formula for the chi-square is:

$$
\chi^{2}=\sum \frac{(o-e)^{2}}{e}
$$

Where: $\chi^{2}=$ chi-square

$\mathrm{o}=$ observed frequency

$\mathrm{e}=$ expected frequency

$\Sigma=$ summation

\section{Data Presentation and Analysis}

A total of 500 questionnaires were distributed to the respondents in this order: 400 to the staff of the council and 100 to the residents of the rural area. 150 were validly filled and returned from the council and 50 from the respondents, making a total of 200 questionnaires retrieved and analysed.

Table 1: Length of Residence of the Respondents in Their Respective Rural Areas

\begin{tabular}{|l|l|l|l|l|l|}
\hline Alternative & $\begin{array}{l}\text { Less than } 1 \\
\text { year }\end{array}$ & $1-5 \mathrm{yrs}$ & $5-10 \mathrm{yrs}$ & $\begin{array}{l}10 \text { yrs and } \\
\text { above }\end{array}$ & Total \\
\hline Freq/Per $(\%)$ & $5(10 \%)$ & $5(10 \%)$ & $10(20 \%)$ & $30(60 \%)$ & $50(100)$ \\
\hline
\end{tabular}

By normal standards, residents who have lived in an area for more than a year are sufficiently experienced to analyse services delivery and suggest improvement measures. Only $10 \%$ have lived in their respective areas less than one year. The remaining $90 \%$ have stayed more than one year and above. Therefore, resident respondents are in a vantage position and their 
opinions are therefore dependable.

Table 2: Responses on the State of Social Services Delivery in Rural Areas of Gwagwalada

\begin{tabular}{|l|l|l|}
\hline Alternative & Frequency & Percentage \\
\hline Adequate & 59 & 30 \\
\hline Not adequate & 141 & 70 \\
\hline Total & $\mathbf{2 0 0}$ & $\mathbf{1 0 0}$ \\
\hline
\end{tabular}

Source: Field Survey, 2011.

The above depicts the respondents' opinion on the adequacy or not of the social services administered in rural areas of Gwagwalada which include: Basic primary education, Primary Health Care (PHC), Good water, Housing, Hostel accommodations for destitute. Overwhelming majority represented by $70 \%$ said it is not adequate, while $30 \%$ said that it is adequate. The above indicates that the social service delivery is not adequate in Gwagwalada Area Council.

Table 3: Responses as Regard Whether the Following Factors Militate Against Effective Administration of Social Services in Gwagwalada Area Council or Not.

\begin{tabular}{|l|l|l|l|}
\hline \multirow{2}{*}{ Alternative } & \multicolumn{2}{l}{ Frequency/ Percentage } & \\
\cline { 2 - 4 } & Yes & No & Total \\
\hline Inadequate and incompetent social workers & $195(97.5 \%)$ & $5(2.5 \%)$ & $200(100 \%)$ \\
\hline $\begin{array}{l}\text { Inability on the part of the council to include the } \\
\text { rural beneficiaries in the design and implementation } \\
\text { of social services }\end{array}$ & $175(87.5 \%)$ & $25(12.5 \%)$ & $200(100 \%)$ \\
\hline $\begin{array}{l}\text { Lack of motivation on the part of the workers } \\
\text { Inadequate fund }\end{array}$ & $185(92.5 \%)$ & $15(7.5 \%)$ & $200(100 \%)$ \\
\hline $\begin{array}{l}\text { Poor networking with other organisations involved } \\
\text { in social service provision }\end{array}$ & $179(89.5 \%)$ & $21(10.5 \%)$ & $200(100 \%)$ \\
\hline
\end{tabular}

Source: Field Survey, 2011.

The table 3 above shows the opinions of the respondents as regards the factors thwarting effective administration of social services in Gwagwalada Area Council. 97.5 percent of the total respondents agreed that inadequate and incompetent social workers are a factor militating against administration of social services. Whereas, only 2.5 percent disagreed that 


\section{Macrothink}

it is not a factor. The conclusion is that it is a factor thwarting effective administration of social services, since majority represented by $97.5 \%$ perceived it in that direction.

Similarly, $87.50 \%$ of the total respondents were of the opinion that failure on the part of the council to involve the beneficiaries in the conception, design and implementation is also another factor. Only 12.5 percent disagreed that it is never an obstacle to effective administration of social services in Gwagwalada Area Council. The wide margin in the percentage portrays that it is a factor inhibiting effective administration of social services.

Likewise, poor motivation on the part of the council was also considered by the respondents as a factor thwarting effective administration of social services in the council. 92.5 percent agreed to this effect whereas only 7.5 percent did not agree. The conclusion is that poor motivation on the part of staff is also a factor militating against effective administration of social services in the council.

Contrastingly, inadequate fund was not considered among the factors inhibiting effective administration of social services. Overwhelming majority represented by 98.5 percent was of opinion to that effect. Only 1.5 percent of the total respondents agreed that it is among the factor obstructing effective administration of social services. The influence is that it is never a factor since majority said so.

But poor networking with other organisations involved in social service provision with the council was also rated as a factor. 89.5 percent were of the opinion that it is a factor. Only 10.5 percent disagreed. The conclusion is that it is a factor militating against effective administration of social services.

\section{Hypothesis}

$\mathrm{H}_{\mathrm{o}}$ : There is no relationship between involvement of the rural residents in administration of social services and rural development.

$\mathrm{H}_{1}$ : There is a relationship between involvement of the rural residents in administration of social services and rural development.

\begin{tabular}{|l|l|l|l|}
\hline Alternative & Rural Residents & Staff of the Council & Total \\
\hline Yes & 34 & 145 & 179 \\
\hline No & 16 & 5 & 21 \\
\hline Total & $\mathbf{5 0}$ & $\mathbf{1 5 0}$ & $\mathbf{2 0 0}$ \\
\hline
\end{tabular}

Workings for the expected

$\mathrm{Fe}=\underline{\mathrm{RT} \times \mathrm{CT}}$

GT 


\section{MlMacrothink}

$$
\begin{array}{lll}
\text { Rural Residents } & \text { Yes } & \text { No } \\
\frac{179 \times 50}{200}=44.75 & \underline{21 \times 50} \\
& 200=5.25
\end{array}
$$

Staff of the Council Yes

No

$$
\frac{175 \times 150}{200}=134.25 \quad \frac{21 \times 150}{200 \quad=15.75}
$$

\begin{tabular}{|l|l|l|l|l|}
\hline Fo & Fe & Fo-Fe & $(\text { Fo-Fe })^{2}$ & $\frac{(\mathbf{F o}-\mathbf{F e})^{2}}{\mathbf{F e}}$ \\
\hline 34 & 44.75 & 10.75 & 115.5 & 2.58 \\
\hline 16 & 5.25 & 10.75 & 115.5 & 22 \\
\hline 145 & 134.25 & 10.75 & 115.5 & 0.86 \\
\hline 5 & 15.75 & 10.75 & 115.5 & 7.33 \\
\hline & & & $\chi^{2}=32.77$ \\
\hline
\end{tabular}

\section{Decision}

The hypothesis indicates that the null hypothesis should be rejected and alternate accepted since chi-square calculated 32.77 are greater than the observed of 3.84. This suggests that rural development cannot be divorced from involvement of people in the process of administering social services. Their involvement creates that sense of belonging and ownership of the services and hence their improved contribution in all ramification. In this dimension, it becomes rural development with them and not for them as their aspiration and wishes would be concretely captured.

\section{Results and Discussion}

No doubt, the analysis revealed that social services in the rural setting of Gwagwalada Area Council has not been adequately and effectively carried out due to the identified factors that militate against proper administration of social services in the Council's rural communities. Information obtained through the questionnaires analysed portrayed inadequate and incompetent social workers, inability to adopt participatory approach in the conception, design and implementation of social services with the beneficiaries, poor motivation and poor networking with other organisations involved in social service provision in the council as the key factors. Funding was not considered any serious factor. The details supported with personal observation and interview is as follows. 


\section{MInstitute Macrothink}

i. Inadequate and incompetent staff is actually a problem militating against effective administration of social services in the council. The health personnel especially the field officers complained that they needed extra staff to boost their efficiency. And again most of the administrative staff interviewed in the council especially those in social welfare and community development units did not majored in disciplines related to the nature of the work they are assigned to do. It is expected that this type of unit should have holders of diploma or B.Sc. social work. But the reverse is the case, hence, the high level of incompetence during initiation of ideas in this dimension.

ii. More so, inability on the part of the council to adopt participatory approach in the conception, design and implementation of social services with the beneficiaries as revealed by questionnaires was also re-confirmed during interview with some of the inhabitants of the rural areas. For instance, in some of the wards visited, the residents attested to some of the developmental efforts of the council. They were of the view that the council fenced Christians and Muslims burial ground as well as fencing of a motor park. However, the rural communities complained that their wishes and aspirations transcend these efforts. Hence they were of the view that if the council had contacted them before embarking on these projects, they would have made their own input and also identify their priority needs. It means that the development approach was for them and not with them. In one of the L.E.A. primary schools visited, the council was highly praised for building one block of classroom with an office. Yet the principal complained that what they actually needed most now is a library. This is also contrary to their felt-needs.

iii. Apart from the above, poor motivation on the part of the workers was also considered a factor in the questionnaires processed. This is certainly a factor as most of the staff complained of lack of furniture and some other materials. The employees of L.E.A. primary schools complained bitterly about the delay in the payment of their salaries. For them, the delay is caused by the fact that two bodies are involved in the payment of their salary; that is Universal Basic Education Board (UBEB) and the Area Council. Due to this joint arrangement, their salaries are not processed on time, and hence, they are paid late. This was considered by them as demoralising.

iv. Poor networking is also another factor. There are donor agencies and other private organisations that are into provision of social services in the council. However, the questionnaires revealed that the area council is not networking with these organisations as partners. The consequence is duplication of efforts.

v. However, funding was not considered as a factor inhibiting effective administration of social services. The budgetary allocation for development according to the respondents interviewed is reasonable enough to transform the rural areas of the Council, but, the reverse is the case.

The hypothesis which focused on the relationship between involvement of the rural residents 
in administration of social services and rural development revealed that there is positive relationship. This means that when the inhabitants of rural areas are involved in the conception, design and implementation, there would be rural development. Whereas they are not involved as is the case in rural areas of Gwagwalada, there would be no meaningful development as any developmental efforts would be contrary to their felt-needs, which invariably is a wasted effort.

\section{Summary of Findings}

The following key factors emerge from the research findings:

i. Basically, the Council lacks the ideas and the abilities to integrate the rural dweller in the design and implementation of social services delivery. This could be due to lack of trained specialists or social workers, who should visit the rural areas, identify their basic needs and intimate the council accordingly. The consequence is misplacement of priorities;

ii. The Council lacks strategic networking ability with other stakeholders such as non-governmental organisations and other donor agencies involved in social services provision within the council, thus leading to duplication of efforts;

iii. Field officers in some of the social facilities centres are not motivated due to inadequate or lack of working materials;

iv. The settlement pattern of indigenes of rural communities in Gwagwalada is the nucleated type and scattered, thus making it difficult for the Council staff to have a baseline data for development planning and intervention in social service provision for rural development of the council.

\section{Conclusion and Recommendations}

Development as rightly posited from the beginning must be human-centred. In the absence of integrating human elements within a development efforts or process, such development may not be rightly described as development. Since the Area Council often carry out social projects that hardly reflect the immediate needs of the rural dwellers, their development efforts will continue to yield unfavourable results. Thus, a lot needed to be done to reverse the trend in order to improve the rural development of the areas. Hence, the following are recommended to strengthen effective administration of the social services in the area council:

i. The Council should make design and implementation process of the social service as a participatory process in order to arrive at a set of principles and areas for action that are based on the aspiration and views of the residents of rural communities.

ii. Impact assessment after the services have been provided might be very useful as this would enable the Council to know whether the services provided are meeting up with needs of the users.

iii. Recruitment of personnel into the social welfare units must be based on possessing relevant qualifications such as diploma or B.Sc. in Social Work. This is 
because it is the unit that is at the heart of initiating policy in terms of social services administration.

iv. The council should provide conducive working environment for the field workers, since most of them complained of lack of furniture and other basic necessities to carry out their day-to-day activities.

\section{References}

Abdul, M. S. (1989), Rural Development Planning in Nigeria: The Case of Bauchi State Agricultural Programme. A Ph.D. Thesis, Sheffield University.

Adejumobi, S. (1999), Privatisation Policy and Delivery of Social Welfare Services in Africa: A Nigerian Example in Journal of Social Development in Africa Vol. 14, No. 2.

Akeredolu, E. O. (1993), Rural Development as National Objective in Akeredolu. E. O. (ed), Mass Media and Rural Development in Nigeria. Ibadan: Spectrum Book Ltd.

Akinleye, S. O. (2007), Rural Infrastructure and Household Health Status in Yewa North Local Government Area, Ogun State. In J. O. Y. Aihonsu, O. O. Olubanjo, S. O. Akinleye and P. A. Okuneye (eds) Proceedings of the Farm Management Association of Nigeria.

Aryeetey, E. and Goldslein, M. (N.D.), Social Policy Reform in Africa, Ghana: International Development Research Centre (IDRC).

Babatunde, D. A. (2010), State of Infrastructure and its Impact on the Quality of Life in Gwagwalada Area Council; in O. O., Ogbonna, A. Ogidiolu, S. D. Musa, O. O. Ifatimehi (eds) Book of Abstract on Contemporary Issues in Infrastructural Development and Management in Nigeria for $51^{\text {st }}$ Conference on the Association of Nigerian Geographers (ANG), Department of Geography and Planning, Kogi State University, $7^{\text {th }}-11^{\text {th }}$ March.

Bello, I. B. (1996), Local Government in Nigeria; Evolving a $3^{\text {rd }}$ Tier of Government. Ibadan: Heinemann Education Books.

Constitution of Federal Republic of Nigeria, 1999.

Ekhator, V. E. (2002), Rudiments of Public Administration. Kaduna: Joyce Graphic Publishers.

Ekhator, V. E. (2008), Administration of Social Services in Nigerian Local Government: A Case Study of Gwagwalada Area Council in All Indian Institute of Local Self-Government Quarterly Vol. LXXVIII, No. 2.

Goel, S. L. (1981), Healthcare Administration. New Delhi: Sterling Publishing Pvt. Ltd.

Mobogunje, A. L. (1977), Issues in Nigeria Urbanisation, Proceeding of the Nigerian Economic Society.

Modupe, O. (1996), Rural Areas and Industrialisation in Nigeria, a Paper Presented at the Environment Planning Week, University of Ife, Ile-Ife.

Muhammed, I. (2005), Social Welfare Administration, an Introductory Text. Kaduna: Alinkawo Printing Press. 


\section{Macrothink}

Journal of Public Administration and Governance

ISSN 2161-7104

2012, Vol. 2, No. 3

Olowa, Y. (1987), Dictionary of Social Work Concepts. Lagos: One Plus One Enterprise.

Reports and Analysis of an Opinion and Recommendations Survey on Water and Electricity Services in Gwagwalada and Abuja Municipal Area Council in the FCT by Civil Society Coalition for Poverty Eradication (CSCPE, 2008).

Rouseau. J. J. (1913), The Social Contract and Discourse. London: Everyman's Library.

Smalley, R. E. (1996), Theory for Social Work Practices. New York: Columbia University Press.

Spiker, P. (1995), Social Policy: Themes and Approaches. New Jersey: Prentice Hall.

Steward, F. (1985), Basic Needs in Developing Countries. Baltimore: John Hopkins University Press.

World Bank (1997), Sri Lanka Impact Evaluation Report, Second Rural Development Project. World Bank: Operation and Evaluation Department, Washington D.C. 